\title{
Adolescent Girls Empowerment Program (AGEP): Savings account
}

Population Council

Follow this and additional works at: https://knowledgecommons.popcouncil.org/departments_sbsr-pgy

Part of the Demography, Population, and Ecology Commons, Family, Life Course, and Society Commons, International Public Health Commons, and the Women's Health Commons How does access to this work benefit you? Let us know!

\section{Recommended Citation}

"Adolescent Girls Empowerment Program (AGEP): Savings account," brief. Lusaka: Population Council, 2016. 


\section{ADOLESCENT GIRLS EMPOWERMENT PROGRAM (AGEP): SAVINGS ACCOUNT}

\section{INTRODUCTION}

Linking girls to formal savings products has the potential to instill a culture of savings at a young age and develop positive money management skills to allow girls to build their own economic assets, which, in turn would allow them to provide for themselves, manage emergencies, and help them make safer and healthier decisions. The lack of financial resources has been identified as a key driver of teenage pregnancy, which is linked to many other outcomes such as early marriage and educational attainment. ${ }^{1,2}$ Therefore, for both of these reasons, working with girls to save, as well as be aware of the risks of depending on others for money, is not only an economic strengthening intervention, but also has the potential to have a longer term effect on sexual behavior and health outcomes.

Through the Adolescent Girls Empowerment Program (AGEP), the Population Council and partners implemented a social, health, and economic asset-building program for over 10,000 vulnerable adolescent girls aged 10-19 years in Zambia. The AGEP intervention was comprised of three major components: 1) weekly safe spaces groups in which girls met once a week over the course of two years for training on sexual and reproductive health, life skills and financial education; 2) a health voucher that girls could use at contracted private and public facilities for a package of general wellness and sexual and reproductive health services; and 3) a saving account that was designed specifically to be girl-friendly.

A randomized controlled trial (RCT) that will be completed in 2017 will evaluate the impact of AGEP. Communities where AGEP was being implemented were randomly assigned different versions of the intervention-including safe spaces only, safe spaces with health vouchers and the full program (safe spaces, health vouchers and savings accounts).

\section{A GIRL-FRIENDLY SAVINGS ACCOUNT}

The Population Council worked in partnership with National Savings and Credit Bank (Natsave), a Zambian parastatal financial institution, and Making Cents International (MCl), a Washington, DC based consulting firm with expertise in

\footnotetext{
${ }^{1}$ Mathur, S., Green, M., \& Malhotra, A. (2006). Too Young to Wed: The Lives, Rights and Health of Young Married Girls.

2 UNICEF. (2014). Ending child marriage: progress and prospects. New York: UNICEF.
}

The Population Council conducts research and delivers solutions that 
providing technical assistance on youth friendly financial product development to develop a bank account that was specifically tailored to the needs of young girls.

The selection of the financial institution was critical to the success of the development of the "Girls Dream" savings account. Natsave had a sincere commitment from the Managing Director to the objectives of establishing a youth friendly financial instrument. In the "Girls Dream" account they recognized a direct match between their mission to reach the financially excluded and goals of AGEP, as well as good fit with their business model. Further, Natsave was well positioned to develop such an account due to their experience developing products for underserved market segments.

Prior to the account development phase, $\mathrm{MCl}$ conducted market research with adolescent girls who were in rural and urban areas, in school and out of school, and younger and older to determine their cash flows, their money management needs and their preferences for a savings product.

Key findings of the market research in the targeted communities indicated that adolescent girls:

- Had sufficient existing (or potential) income sources;

- Had flexible expenditure patterns to be able to save money (on a regular, seasonal, or irregular basis);

- Were already motivated to save money (or interested in training on saving money); and

- Would use a savings account product (if designed according to their needs) in order to save money for both short and long term goals.

\section{PRODUCT DESIGN AND TESTING}

Specific features of the Girls Dream account made it accessible and affordable for adolescent girls. The account had a low minimum balance of $2.5 \mathrm{ZMW}(\$ 0.25)$ to open, and any amount could be deposited or withdrawn with no fee. Because the majority of the AGEP girls were not yet of age to obtain a required National Registration Card (NRC), Natsave requested a special waiver from the Bank of Zambia to exempt AGEP girls under 18 from having to present a NRC to open an account. Beyond the completed account application form, the Girls Dream account opening requirements included a photo of the girl, a copy of the co-signer's NRC (a woman aged 18 or

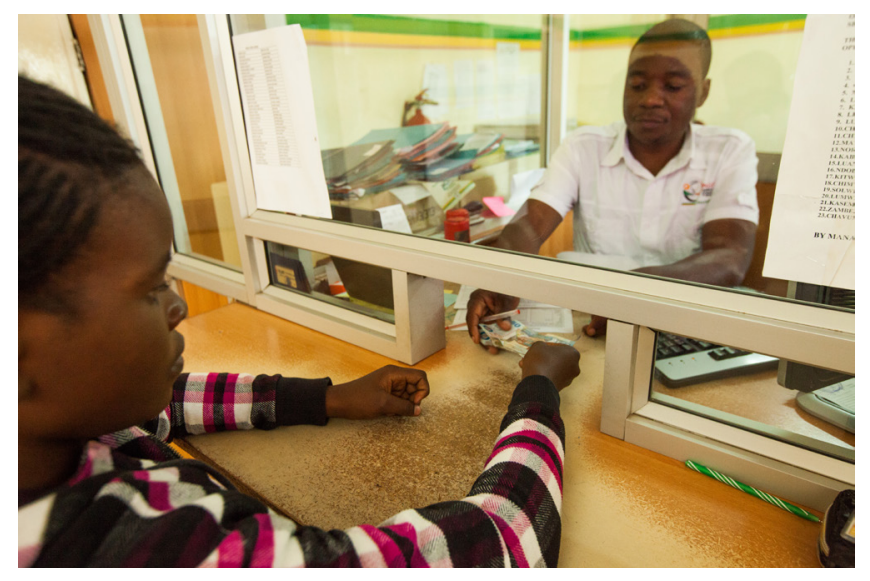

older) and a supporting letter signed and stamped by Population Council recommending the applicant to open an account. With this arrangement, girls were able to make deposits on their own with a co-signatory assisting with account opening and withdrawals.

\section{ACCOUNT OPENING PROCESS, PRODUCT CHAMPIONS AND STAFF TRAINING}

Prior to account opening, mentors in the savings groups were trained by AGEP staff on the savings account features and account opening process. An orientation session was held during a safe spaces group meeting with the girls and their co-signatories to inform them of the account and begin the account opening paperwork. Finally, a field trip to the branch was organized for girls and their co-signatories to complete the account opening process, make an initial deposit and meet Natsave branch staff.

At the outset, Natsave headquarters (HQ) and branch level staff were trained on the Girls Dream business case, account features and operational guidelines to administer the account. Each Natsave branch designated a Girls Dream product champion to serve as the branch point person for AGEP girls when opening their accounts and during subsequent visits to the bank. Product champions were selected based on their interest in working to empower adolescent girls in the community, supporting them as they accessed services in the formal financial sector. Beyond providing direct support services to the Girls Dream account holders, product champions served as branch advocates to ensure that other staff members understood the business case and why it was important to serve the AGEP girls fairly. 
TABLE 1: Account usage summary

\begin{tabular}{|l|c|c|c|c|}
\hline & $10-14$ Rural & $10-14$ Urban & 15-19 Rural & 15-19 Urban \\
\hline \# of deposits & & & & \\
1 deposit & $66 \%$ & $67 \%$ & $75 \%$ & $70 \%$ \\
2 deposits & $20 \%$ & $16 \%$ & $19 \%$ & $13 \%$ \\
3+ deposits & $14 \%$ & $17 \%$ & $6 \%$ & $17 \%$ \\
\hline \% withdrew & $1 \%$ & $4 \%$ & $2 \%$ & $9 \%$ \\
\hline Mean Deposit Size (ZMW) & 16 & 29 & 11 & 89 \\
Account Balance (ZMW) & 5 & 2.5 & 5 & 2.5 \\
\hline
\end{tabular}

Exchange rate as of December 2016 approximately $10 \mathrm{KW}$ per $\$ 1$.

Over a year after the launch of the account, additional interviews conducted with AGEP girls revealed that there was a lack of 'youth friendliness' at the Natsave branches. In response to this issue, Natsave and Population Council conducted a youth friendly financial services training for selected Natsave staff. The training provided new training on how to improve the youth friendliness of the branch services as well as refresher training on the aim of AGEP, the Natsave business case for the Girls Dream savings account and the account features. Also the training provided a platform to give branch staff feedback collected from bank account holders, including their fears and experiences when accessing services at the branches.

\section{ACCOUNT USAGE}

Account usage, although low, was on par with other similar adolescent or child savings accounts developed through various financial inclusion programs. ${ }^{3}$ Due to the study design, a third of girls were eligible to open savings accounts. Of those who did, about a third of girls made an additional deposit into their account after the initial deposit. Few girls (3\%) withdrew from their accounts during the course of the intervention.

\section{SAVINGS AND FINANCIAL LITERACY OUTCOMES}

As the financial education curriculum was a part of the safe space groups, all girls were exposed to lessons on the importance of saving, budgeting, and prioritizing different kinds of spending, as well as the risks of certain kinds of income. However, girls who were eligible to open a
Girls Dream savings account had higher financial literacy scores, greater savings behaviour and larger amounts saved (see Table 2). Therefore, having a savings account seems to reinforce what girls are learning and gives them an opportunity to put the skills they learn in theory into actual practice. This confirms the findings of two recent systematic reviews on financial education, which both found that financial education is more effective when given the chance for immediate application. ${ }^{4}$

Process evaluation interviews conducted periodically through the intervention to assess the implementation of the savings account component confirmed that girls with a savings account felt motivated to save informally, even if they had not yet made a deposit, so they could save up enough for it to be worth a trip to the bank.

TABLE 2: Relative percentage point increase attributed to the AGEP program

\begin{tabular}{|l|c|c|c|}
\hline & AGEP & $\begin{array}{c}\text { Attended } \\
\text { FE Session }\end{array}$ & $\begin{array}{c}\text { Opened a } \\
\text { Savings } \\
\text { Account }\end{array}$ \\
\hline $\begin{array}{l}\text { Improvement on } \\
\text { the financial } \\
\text { literacy score }\end{array}$ & $3 \%$ & $3 \%$ & $4 \%$ \\
\hline $\begin{array}{l}\text { Girls saving in the } \\
\text { past six months }\end{array}$ & $5 \%$ & $9 \%$ & $17 \%$ \\
\hline $\begin{array}{l}\text { Girls saving more } \\
\text { than \$2 (20 } \\
\text { Kwacha) in the } \\
\text { past six months? }\end{array}$ & $3 \%$ & $5 \%$ & $10 \%$ \\
\hline
\end{tabular}

3 YouthSave Consortium. 2015. YouthSave 2010-2015: Findings from a Global Financial Inclusion Partnership. https://na-production.s3.amazonaws.com/documents/YouthSave_2010_2015.pdf

4 Miller, M., Reichelstein, J., Salas, C., and Zia, B. 2014. Can You Help Someone Become Financially Capable? A Meta-Analysis of the Literature. Policy Research Working Paper 6745. World Bank. 


\section{RECOMMENDATIONS}

From the Girls Dream experience, the key recommendations for developing and administering an account targeting adolescent girls include the following:

- Support from the executive level of management at the financial institution is critical;

- Branch level staff buy-in for the product, both at management and frontline levels, is essential. Branch and headquarter trainings are important, particularly to understand the business case for the account as well as the importance of youth friendly financial services;

- Girl-friendly regulatory requirements will make the account more accessible. This may require a special agreement or legal waiver from the country's regulatory body (typically a Central Bank);

- Do not make assumptions on what girls want in a savings product. Ask them directly. Market research and product testing is important;

- However, balancing girls' preferences with bank demands is critical to create a viable and sustainable product;

- It is important to sensitize the parents/guardians and community members about the product features and benefits of girls saving;

- Access to formal financial services can be a catalyst for both informal and formal savings activity; and

- Financial education is a critical component to the successful roll-out of financial services for vulnerable adolescent girls.

As the study continues to follow the adolescent girls for two additional years after the program, time will tell if the positive changes in financial literacy and savings behaviour are sustained and if they translate into longer term changes in sexual health behaviours.

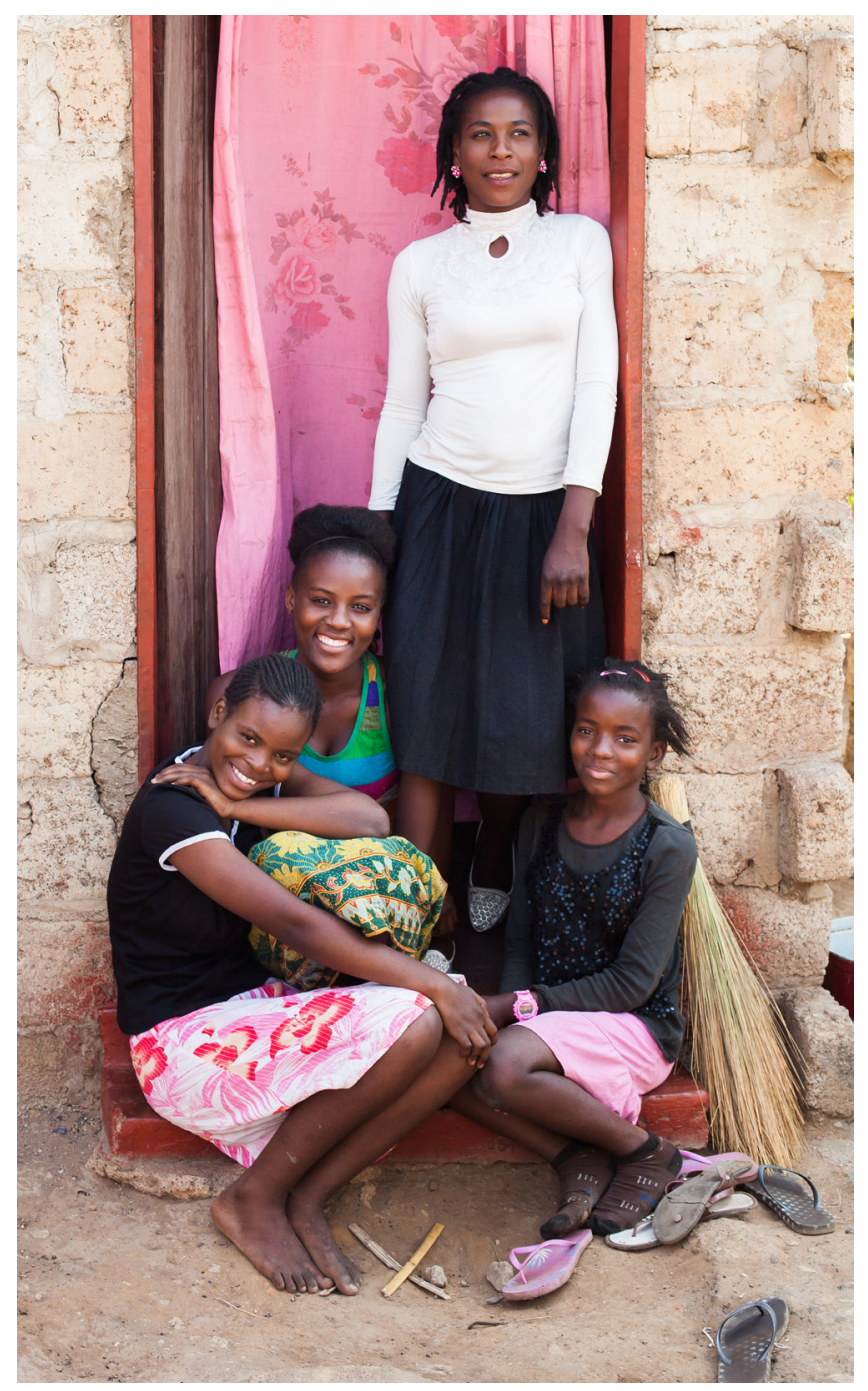

Population Council, Zambia

Plot 3670, No. 4

Mwaleshi Road, Olympia Park

Lusaka, Zambia

Tel: +260 211295925

email:info.zambia@popcouncil.org

Photos: John Healey

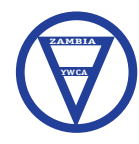

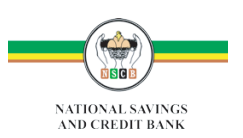

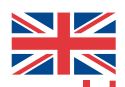

UKaid
POPULATION COUNCIL

Ideas. Evidence. Impact. 